\title{
EXPERIMENTAL AND NUMERICAL ANALYSIS OF FLEXURAL COMPOSITE BEAMS WITH PARTIAL USE OF HIGH STRENGTH/HIGH PERFORMANCE CONCRETE
}

\author{
Andrzej Lapko1, Barbara Sadowska-Buraczewska ${ }^{2}$, Andrzej Tomaszewicz ${ }^{3}$ \\ 1,2Białystok Technical University, 15-351 Biatystok, ul. Wiejska 45E, Poland. ${ }^{1}$ E-mail: lapko@pb.bialystok.pl \\ ${ }^{2}$ E-mail: bsadowska@pb.bialystok.pl \\ ${ }^{3}$ Senior Expert Group at Tekna, Oslo, Norway. E-mail: andrzej@tomaszewicz.no
}

Received 21 Jan 2005; accepted 29 Apr 2005

\begin{abstract}
The paper summarises the experimental and numerical analysis of flexural capacity and deformability of structural concrete beams prepared as composite members consisting of two concrete layers made of reinforced normal concrete and high-performance concrete (HPC).

The reinforced concrete composite beams used in the tests were prepared in full scale with the cross-section of $120 \mathrm{x}$ $200 \mathrm{~mm}$ and the effective span of $2950 \mathrm{~mm}$. The basic samples were composed in two layers consisting of highperformance concrete as the top layer, and normal strength concrete. The results of the analyses confirm a significant improvement of structural properties of composite beams in comparison to the beams prepared totally of normal concrete, and in some cases also in comparison with the beam totally made of HPC.
\end{abstract}

Keywords: composite beam, high-performance concrete, flexural capacity, deformability, full-scale beam tests.

\section{Introduction}

In the last decade HPC-HSC are more widely used in practice parallel with growing interest of researchers to precisely describe mechanical properties and methods of design of structural members [1-4]. Simultaneously some new conceptions in this field have been presented, for example, in composite structures, where HPC-HSC are partially used [5].

As reported by Yamada [6, 7], the structural reinforced concrete and prestressed composite beams with the HSC layer tested in Japan under short-time load, may have improved sectional parameters, eg a higher flexural stiffness and greater bending capacity in comparison to homogenous members, made of normal strength concrete. Hybrid reinforced concrete composite beams show intermediate behaviour between reinforced concrete beams made of high-strength concrete and beams of normal strength concrete.

Our previous studies conducted on models of reinforced concrete composed with a partial use of HPC beams under short-time loading revealed the significant increase of beam stiffness and ultimate capacity in bending, compared to control RC beams made of normal concrete [8-10]. In this paper the selected results of experimental and numerical analysis of such composite beams in natural scale are presented and discussed.

\section{Experimental investigations}

The reinforced concrete composite beams were prepared with the cross-section of $120 \times 200 \mathrm{~mm}$ and the effective span of $2950 \mathrm{~mm}$. The composite beams were cast, as follows:

- Normal concrete as the bottom layer

- Adhesive layer

- HPC layer on the top of the beam with the thickness of $40 \mathrm{~mm}$.

The HPC-HSC composition was elaborated [11] based on the cement type CEM I-42,5, natural fine aggregate $0-2 \mathrm{~mm}$, and the fine basalt aggregate with fractions $2-8 \mathrm{~mm}$ together with the silica fume and superplasticising admixture Dynamon SX-N from Rescon Mapei AS. In normal concrete composition the same type of cement and natural fine aggregate of 0-2 $\mathrm{mm}, 2-8 \mathrm{~mm}$ has been used. The surface contact between normal and HPC concrete layers in composite beams was improved by a liquid adhesive agent from Ombran System; at the top of the normal concrete a hardened layer before the HPC layer was cast. Typical characteristics of concrete mixes and mechanical properties in hardened state of concrete used in the experimental beams are given in Table 1.

After 28 days curing of samples in air-dry environment, the tests were performed, including the observations and measurement of selected physical properties: 
Table 1. Data composition and properties of concrete used in tests

\begin{tabular}{c|c|c|c|c|c|c}
\hline \multirow{2}{*}{ Concrete } & \multirow{2}{*}{$\begin{array}{c}\text { Concrete } \\
\text { classes }\end{array}$} & \multicolumn{3}{|c|}{$\begin{array}{c}\text { Properties of concrete mix } \\
\text { per } 1 \mathrm{~m}^{3}\end{array}$} & \multicolumn{2}{c}{$\begin{array}{c}\text { Mean strength of } \\
\text { concrete }\end{array}$} \\
\cline { 3 - 7 } & & $\mathrm{w} / \mathrm{c}$ & $\mathrm{k} / \mathrm{c}$ & $\mathrm{s} / \mathrm{c}$ & $\begin{array}{c}\mathrm{f}_{\text {cm cube }} \\
{[\mathrm{MPa}]}\end{array}$ & $\begin{array}{c}\mathrm{f}_{\mathrm{ctm}, \mathrm{sp}} \\
{[\mathrm{MPa}]}\end{array}$ \\
\hline $\mathrm{HPC}$ & $\mathrm{B} 105$ & 0,25 & 2,42 & 0,10 & 115,40 & 6,2 \\
\hline $\mathrm{N}$ & $\mathrm{B} 25$ & 0,50 & 4,13 & --- & 25,35 & 2,1 \\
\hline
\end{tabular}

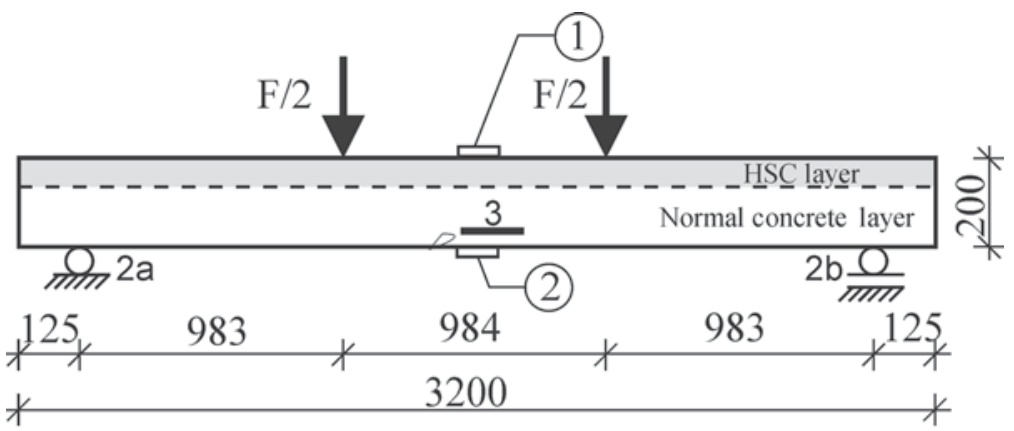

a)

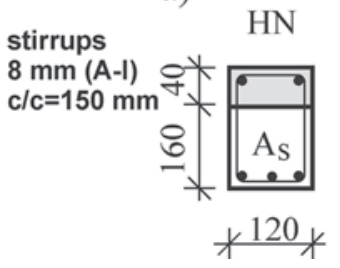

b)

$\mathrm{H}$

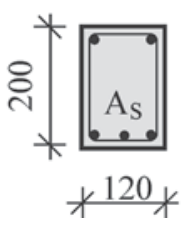

c)<smiles>[AlH2]</smiles>

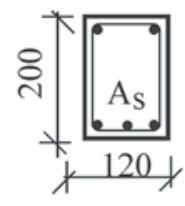

Fig 1. Loading scheme, cross-sections and zones of measurements in the tested beams:

a) composite beam, b) control homogeneous beam made of HPC, c) control normal concrete beam, 1 - zone of compressive strain measurement, $2,2 \mathrm{a}, 2 \mathrm{~b}$ - zones of deflection registration, 3 - tensile steel strain measurement

- Short-time concrete compressive strains on the top of beams.

- The beam deflections measured at a half span of each beam and near to the bearings.

- The analysis of crack pattern during loading.

- Bending capacity for basic and control beams.

- Concrete strains at the cross-section height on the side surface of the beam.

Based on preliminary model beam analyses, the tested beams were singly reinforced by the ribbed steel bars class A-III $\left(f_{y d}=455 \mathrm{MPa}, E_{s}=200 \mathrm{GPa}\right)$ according to Polish Code PN-B-03264:2002 [12] with $3 \%$ reinforcement ratio.

The characteristics of main and control beams and reinforcement in respective series are given in Table 2.

Table 2. Main characteristics of tested composite beams

\begin{tabular}{l|c|c|c}
\hline $\begin{array}{c}\text { Type of the } \\
\text { beam }\end{array}$ & $\begin{array}{c}h_{H P C} / h_{\text {tot }} \\
\text { layer depth ratio }\end{array}$ & $\begin{array}{c}\text { Tension } \\
\text { steel } \\
\text { of the beam }\end{array}$ & $\begin{array}{c}\text { Reinforce- } \\
\text { ment ratio }\end{array}$ \\
\hline Composite HN & 0,20 & \multirow{2}{*}{$3 \phi 16$} & $3 \%$ \\
\hline Control H & 1,00 & \multirow{2}{*}{$3 \%$} & \\
\hline Control N & 0,00 & & \\
\hline
\end{tabular}

- $h_{H P C}$ and $h_{t o t}$ - the depth of the layer made of HPC and the total depth of the beam
Each series consists of three beams. Cross-sections of the specimens and loading conditions during testing are shown in Fig 1.

The view of the composite beam is presented in Fig 2. The HPC layer at the top is shown by grey colour.

The concrete strains and beam deflections were measured using a computerised system of registration

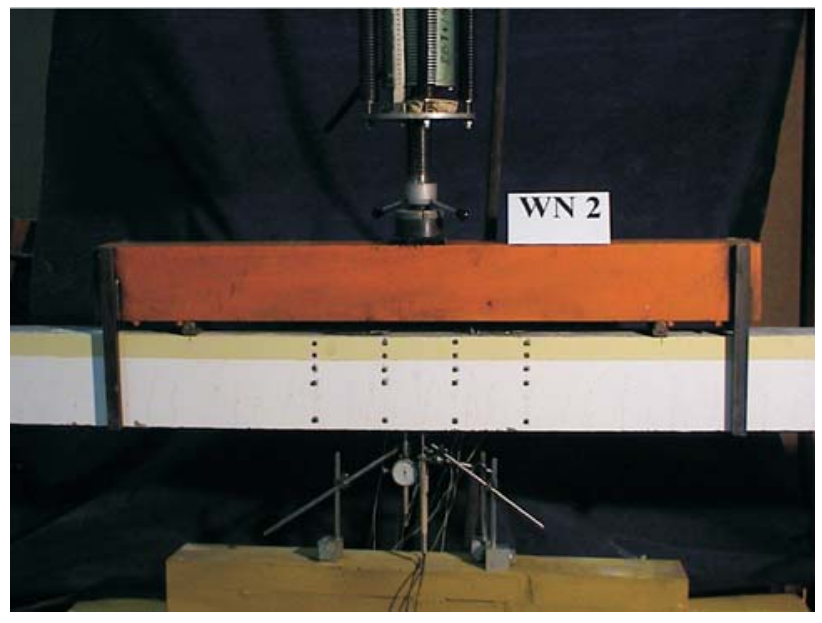

Fig 2. The composite beam on the test stand in the testing machine 
DaqBook made in USA equipped by inductive sensors of Peltron type with the reading accuracy of $0,001 \mathrm{~mm}$. The concentrated load subjected to the tested beams was registered with the accuracy of $100 \mathrm{~N}$.

\section{Analysis of short-time effects under bending}

The measured values of compressive strains and beam deflections are related to the mean values for all the samples tested in each series for the chosen force level. Selected results of investigations, describing experimental relationships between loading force $F$ and deflection $a$ and compressive strains $\varepsilon_{c}$ for composite beams and also for homogeneous control beams are presented in Fig 3a, 3b.

As we can see, the composite beams reveal distinctly lower concrete compressive strains, in comparison not only with normal concrete control beams but also with control beams made totally of HPC.

The quantitative effects of the use of HPC layer on the composite beam behaviour has been defined as the coefficient $k_{\alpha}$ computed by the general formula [9]:

$$
k_{\alpha}=\alpha_{N} / \alpha_{H P C},
$$

where:

$\alpha_{N}$ - effects (strains, deflection, crack width) measured on homogenous control beams made of normal strength concrete;

$\alpha_{H P C}-$ respective effects measured on the beams made with the use of HPC layer.

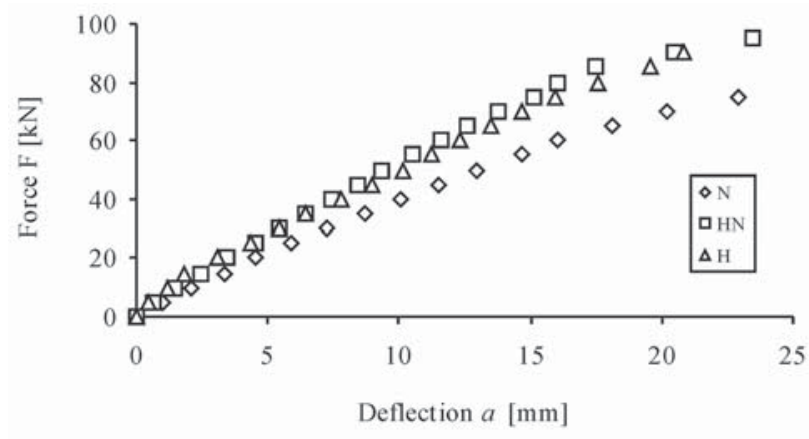

Fig 3a. Experimental relationships obtained from an experimental analysis of loading force $F$ deflection

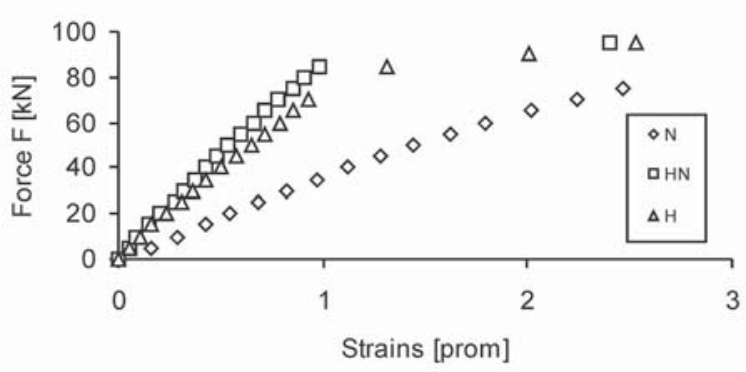

Fig 3b. Experimental relationships obtained from an experimental analysis of loading force $F$ compressive strains
The selected values of coefficient $k$ a computed for measured deflections from the above formula for chosen three levels of the load are presented in Table 3.

Table 3. Quantitative effects of the use of HPC layer on beam deflection

\begin{tabular}{l|c|c|c|c|c|c}
\hline \multirow{2}{*}{ Beam type } & \multicolumn{6}{|c}{ Deflection $a[\mathrm{~mm}]$ of the beam } \\
\cline { 2 - 7 } & $F=45 \mathrm{kN}$ & $F=55 \mathrm{kN}$ & \multicolumn{2}{c}{$F=65 \mathrm{kN}$} \\
\cline { 2 - 7 } & $a$ & $k_{a}$ & $a$ & $k_{a}$ & $a$ & $k_{a}$ \\
\hline Control N & 11,536 & 1,00 & 14,643 & 1,00 & 18,114 & 1,00 \\
\hline $\begin{array}{l}\text { Composite } \\
\text { HN }\end{array}$ & 8,450 & $\mathbf{1 , 3 6}$ & 10,469 & $\mathbf{1 , 4 0}$ & 12,592 & $\mathbf{1 , 4 4}$ \\
\hline Control H & 9,004 & 1,28 & 11,222 & 1,30 & 13,492 & 1,34 \\
\hline
\end{tabular}

The results of investigations in Table 3 indicate that the tested reinforced concrete composite beams made with a partial use of HPC have a relatively higher stiffness in comparison to stiffness of homogenous control beams made of normal concrete. For the load level $50 \mathrm{kN}$ (equal to about $60 \%$ of carrying capacity) the composite beam revealed the stiffness equal or even a little larger than the beam totally made of HPC.

This effects are due to stress and strain state redistribution in the zone of contact between HPC and normal concrete.

\section{Flexural capacity of composite beam}

The tested beams have been statically loaded to failure. The failure mechanism of composite beams was without splitting on the contact surface between HPC and normal concrete layers. The mean values of flexural capacities of the beams of destructive tests for three series are compared in Table 4.

For the considered beams series, the quantitative effect of strengthening by HPC layer on the bending capacity of the beams was evaluated as the experimental coefficient $m$ :

$$
m=M_{b, H P C} / M_{b, N},
$$

where:

$M_{b, H P C}$ - measured mean carrying capacity of the beam made with the use of HPC;

$M_{b, N}-$ measured mean carrying capacity of the normal concrete control beam.

\begin{tabular}{|c|c|c|c|c|}
\hline \multirow[t]{2}{*}{ Beam type } & \multicolumn{2}{|c|}{$\begin{array}{l}\text { Mean carrying } \\
\text { capacity }[\mathrm{kNm}]\end{array}$} & \multicolumn{2}{|c|}{$\begin{array}{l}\text { HPC effect on beam } \\
\text { capacity coefficient } m \\
\text { according to formula (2) }\end{array}$} \\
\hline & $\begin{array}{l}\text { Experi- } \\
\text { mental }\end{array}$ & $\begin{array}{l}\text { Computer } \\
\text { analysis }\end{array}$ & $\begin{array}{l}\text { Experi- } \\
\text { mental }\end{array}$ & $\begin{array}{l}\text { Computer } \\
\text { analysis }\end{array}$ \\
\hline Control N & 36,23 & 35,20 & ---- & ---- \\
\hline Composite HN & 47,37 & 43,27 & 1,31 & 1,23 \\
\hline Control H & 46,05 & 42,60 & 1,27 & 1,21 \\
\hline
\end{tabular}

Table 4. Carrying capacity of beams and the effect of HPC use 


\section{Numerical analysis}

Numerical analysis of given composite beams are performed using the discretisation of the cross-section for $\alpha$ layers and taking into account the non-linear behaviour of concrete in compression and Bernoulli principle.

Concrete relationship $\sigma-\varepsilon$ has been described by the relationship in EC2 [11].

$$
\sigma_{\alpha}=f_{c m} \frac{k \eta_{\alpha}+\eta_{\alpha}^{2}}{1-(k-2) \eta_{\alpha}}, \quad \eta_{\alpha}=\frac{\varepsilon_{\alpha}}{\varepsilon_{c 1}},
$$

where the positive values of $\sigma_{\alpha}$ and $\varepsilon_{\alpha}$ denote tensile stresses and strains in the respective layer $\alpha$.

For the tension in steel reinforcement, the linear relationship has been assumed:

$$
\sigma_{\alpha}= \begin{cases}E_{s} \varepsilon_{\alpha}, & \varepsilon_{\alpha} \leq f_{y d} / E_{s}, \\ f_{y d}, & \varepsilon_{\alpha}>f_{y d} / E_{s} .\end{cases}
$$

The numerical algorithm is based on solving the system consisting of two non-linear equations and two unknowns: $z$ (the neutral axis depth) and $\kappa$ (curvature of section)

$$
\left\{\begin{array}{l}
f(z, \kappa)=\sum_{\alpha=0}^{n} A_{\alpha} \sigma_{\alpha}=0 \\
g(z, \kappa)=\sum_{\alpha=0}^{n} A_{\alpha} \sigma_{\alpha}\left(z-z_{\alpha}\right)-M=0 .
\end{array}\right.
$$

For the numerical solution of this problem, the commonly used iteration method of Newton has been applied. As the initial approximation for the Newton process, the general formulas are used:

$$
z^{0}=\frac{\sum_{\alpha=0}^{n} E_{\alpha} A_{\alpha} z_{\alpha}}{\sum_{\alpha=0}^{n} E_{\alpha} A_{\alpha}} \quad \kappa^{0}=\frac{M}{\sum_{\alpha=0}^{n} E_{\alpha} A_{\alpha}\left(z-z_{\alpha}\right)^{2}}
$$

where:

$\sigma_{\alpha}-$ tensile stresses in the layer $\alpha$,

$\mathrm{A}_{\alpha}-$ cross-sectional area for layer $\alpha$,

$\mathrm{z}_{\alpha}$ - distance of layer a from the bottom,

$\mathrm{E}_{\alpha}-$ coefficient of elasticity for layer $\alpha$.

The cracking effects are modelled by the iteration process in which at any step of design one consecutive layer after cracking, was eliminated.
The condition of elimination of cracking concrete layer $\mathfrak{i}$ was assumed to be:

$$
\sigma_{\alpha}>f_{c t m},
$$

where $f_{c t m}-$ mean tensile strength.

The layers made of steel (modelled steel bars) have been not eliminated.

For concrete, according to prEN [13], basing on mean compressive strength $f_{c m}$ the following properties, have been evaluated:

$$
\begin{gathered}
E_{c m}=22\left[\left(f_{c m}\right) / 10\right]^{-3} \quad \varepsilon_{c 1}=0,7 \cdot f_{c m}^{0,31}, \\
f_{c t m}=\left\{0,30\left(f_{c m}-8\right)^{2 / 3}, f_{c m}\langle 58 M P a,\right. \\
f_{c t m}=\left\{2,12 \ln \left[1+\left(f_{c m} / 10\right)\right], f_{c m} \geq 58 M P a .\right.
\end{gathered}
$$

\section{Numerical simulation of composite beams in full scale}

Based on the given relationships, the computer procedures were elaborated and the numerical simulation of the same composite beams used in experimental investigations were analysed. In the analysis, the respective HPC layer depths were differentiated assuming values equal to $w=20,30,40$ and $50 \mathrm{~mm}$ (giving the nondimmensional ratios equal to 0,$10 ; 0,15 ; 0,20$ and 0,25 of total beam depth).

The numerical analyses of maximum concrete compressive strains, curvature and carrying capacities of the beams were performed. The selected results of respective composite beams for different thickness of HPC layer are shown below in diagrams and tables.

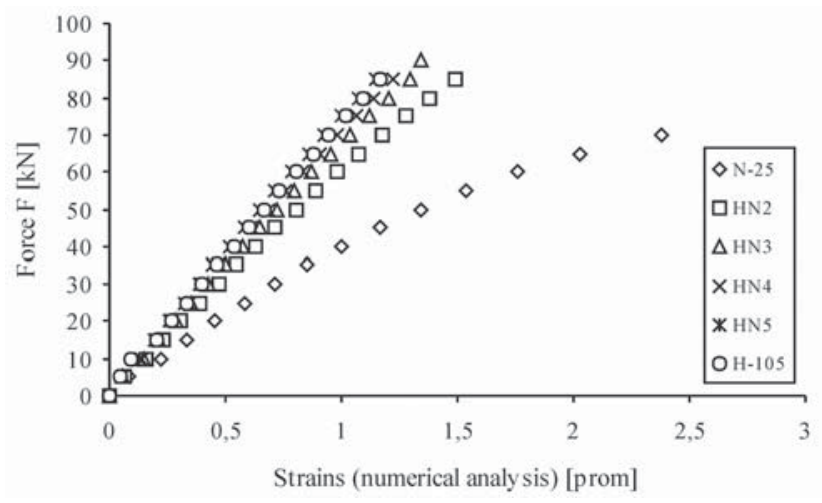

Fig 4. Numerical relationships between load $F$ and compressive strains $\varepsilon_{\mathrm{c}}[\% \mathrm{o}]$ on the top of beams (HN2, $\mathrm{HN} 3$, HN4 and HN5) and control beams made totally of normal strength concrete (B-25) and HPC (B-105)

Table 5. Concrete compressive strains $\varepsilon_{c}[\%]$ on the top of beams (numerical analysis)

\begin{tabular}{l|c|c|c|c|c|c}
\hline \multirow{2}{*}{ Type of beam } & \multirow{2}{*}{\begin{tabular}{c}
$\delta=\frac{w}{h}$ \\
\cline { 3 - 7 }
\end{tabular}} & $\begin{array}{c}F=25 \\
{[\mathrm{kN}]}\end{array}$ & $\begin{array}{c}F=35 \\
{[\mathrm{kN}]}\end{array}$ & $\begin{array}{c}F=45 \\
{[\mathrm{kN}]}\end{array}$ & $\begin{array}{c}F=55 \\
{[\mathrm{kN}]}\end{array}$ & $\begin{array}{c}F=65 \\
{[\mathrm{kN}]}\end{array}$ \\
\hline Control N & $\cdots$ & 0,578 & 0,852 & 1,164 & 1,537 & 2,027 \\
\hline Composite HN 2 & 0,10 & 0,390 & 0,545 & 0,734 & 0,891 & 1,077 \\
\hline Composite HN 3 & 0,15 & 0,351 & 0,497 & 0,648 & 0,793 & 0,953 \\
\hline Composite HN 4 & 0,20 & 0,339 & 0,471 & 0,613 & 0,750 & 0,900 \\
\hline Composite HN 5 & 0,25 & 0,321 & 0,447 & 0,581 & 0,717 & 0,857 \\
\hline Control H & 1,00 & 0,337 & 0,467 & 0,605 & 0,735 & 0,878 \\
\hline
\end{tabular}


Table 6. The quantitative comparison of strains $\varepsilon_{c}[\% 0]$ in composite beams and control beams $(\mathrm{H}, \mathrm{N})$

\begin{tabular}{|c|c|c|c|c|c|c|c|c|c|c|}
\hline & \multicolumn{2}{|c|}{$F=25[\mathrm{kN}]$} & \multicolumn{2}{|c|}{$F=35[\mathrm{kN}]$} & \multicolumn{2}{|c|}{$F=45[\mathrm{kN}]$} & \multicolumn{2}{|c|}{$F=55[\mathrm{kN}]$} & \multicolumn{2}{|c|}{$F=65[\mathrm{kN}]$} \\
\hline$\frac{\mathrm{HN} 2}{\mathrm{~N}}$ & $\frac{0,578}{0,390}$ & 1,48 & $\frac{0,852}{0,545}$ & 1,56 & $\frac{1,164}{0,734}$ & 1,59 & $\frac{1,537}{0,891}$ & 1,73 & $\frac{2,027}{1,077}$ & 1,88 \\
\hline$\frac{\mathrm{HN} 3}{\mathrm{~N}}$ & $\frac{0,578}{0,351}$ & 1,65 & $\frac{0,852}{0,497}$ & 1,71 & $\frac{1,164}{0,648}$ & 1,80 & $\frac{1,537}{0,793}$ & 1,94 & $\frac{2,027}{0,953}$ & 2,13 \\
\hline$\frac{\mathrm{HN} 4}{\mathrm{~N}}$ & $\frac{0,578}{0,339}$ & 1,70 & $\frac{0,852}{0,471}$ & 1,81 & $\frac{1,164}{0,613}$ & 1,90 & $\frac{1,537}{0,750}$ & 2,05 & $\frac{2,027}{0,900}$ & 2,25 \\
\hline$\frac{\mathrm{HN} 5}{\mathrm{~N}}$ & $\frac{0,578}{0,321}$ & 1,80 & $\frac{0,852}{0,447}$ & 1,91 & $\underline{1,164}$ & 2,00 & $\frac{1,537}{0,717}$ & 2,14 & $\frac{2,027}{0,857}$ & 2,36 \\
\hline
\end{tabular}

Table 7. Flexural curvatures $\chi[1 / \mathrm{m}]$ of the composite beams with the ratio $\delta=0,10 ; 0,15 ; 0,20 ; 0,25$

\begin{tabular}{c|c|c|c|c|c|c}
\hline Force & Control & Composite & Composite & Composite & Composite & Control \\
$F[\mathrm{kN}]$ & $N$ & $H N 2$ & $H N 3$ & $H N 4$ & $H N 5$ & $H$ \\
\hline 20 & 0,00548 & 0,00450 & 0,0043 & 0,00424 & 0,0042 & 0,00418 \\
\hline 30 & 0,00846 & 0,00681 & 0,0066 & 0,00644 & 0,0064 & 0,00634 \\
\hline 40 & 0,0117 & 0,00919 & 0,0088 & 0,00863 & 0,0086 & 0,00853 \\
\hline 50 & 0,0152 & 0,0116 & 0,0111 & 0,01084 & 0,0107 & 0,0107 \\
\hline 60 & 0,0193 & 0,0140 & 0,0134 & 0,0131 & 0,0130 & 0,0129 \\
\hline
\end{tabular}

The respective quantitative comparison of strains is presented in Table 6.

Comparative analysis of maximal compressive concrete strains of beams HN2, HN3, HN4, HN5 and homogeneous control beams showed that the strains of the beam HN5 are about two times smaller than the control beams made of normal concrete.

In Table 7 the numerical values of beam curvatures $\chi$ for the beams of types HN2, HN3, HN4 and HN5 for the chosen values of loading forces are presented. The respective relationships $F-\chi$ are shown in Fig 5 .

Comparison of composite flexural beam curvatures $\chi$ with the respective control beam curvatures revealed that the smallest value of curvature was for the beam HN5 $(\delta=0,25)$. For this case the curvature were about $42 \%$ smaller in comparison with the control beam made of normal concrete and almost equal to the curvature of control beam made totally of HPC.

Numerically and experimentally predicted flexural capacities for respective composite and control beams are presented in Table 8. The discrepancies between experimental and numerical results are not significant not larger than $10 \%$.

Table 8. Carrying capacity $M_{R d}[\mathrm{kNm}]$ (experimental and numerical analysis)

\begin{tabular}{l|c|c}
\hline Type of beams & $\begin{array}{c}\text { Carrying capacity } \\
\text { (numerical } \\
\text { analysis) } \\
{[\mathrm{kNm}]}\end{array}$ & $\begin{array}{c}\text { Carrying capacity } \\
\text { (experimental } \\
\text { analysis) } \\
{[\mathrm{kNm}]}\end{array}$ \\
\hline Control $N$ & 35,20 & 36,23 \\
\hline Composite HN 2 & 43,00 & ---- \\
\hline Composite HN 3 & 43,27 & ---- \\
\hline Composite HN 4 & 43,27 & 47,37 \\
\hline Composite HN 5 & 42,90 & ---- \\
\hline Control H & 42,60 & 46,05 \\
\hline
\end{tabular}

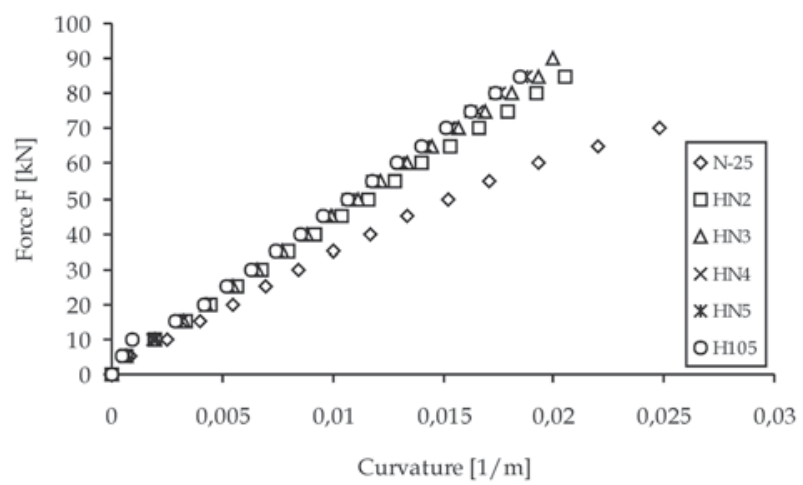

Fig 5. Numerical relationships between load $F$ and curvature $\chi[1 / \mathrm{m}]$ for composite beams $(\mathrm{HN} 2, \mathrm{HN} 3, \mathrm{HN} 4$, $\mathrm{HN} 5)$ and control beams made totally of normal strength concrete (B-25) and HPC (B-105)

The numerical analysis revealed that the composite beams with different depth of HPC layers have the carrying capacity almost equal to the control beam totally made of HPC. Composite beams revealed about $22 \%$ of flexural larger capacity in comparison with normal concrete control beam.

\section{Conclusions}

The experimental and numerical analyses conducted on reinforced concrete composite beams made of normal concrete within HPC layer revealed various positive effects of strengthening the composed beams compared to homogenous, normal strength concrete beams.

Bending tests conformed to significantly reduced compressive strains and deflections measured in composite beams in comparison with the strains and deflections measured in control beams made of normal concrete. This positive static effects can be explained by the redistribution of stresses and strains in the composite beams. 
The influence of HPC layer on flexural carrying capacity of the composite beams with HPC layer depends on reinforcement ratio of beam section. For tested beams with ratio $\rho=3 \%$, the predicted experimentally bending capacity was about $31 \%$ higher, compared to the capacity of homogeneous beams of normal strength concrete.

The analyses showed the possibility of applications of such composite flexural structures in strengthening the structural concrete members in rehabilitation and reconstruction works.

\section{References}

1. Bae, S. and Bayrak, O. Stress block parameters for highstrength concrete members. ACI Structural, Vol 100, Issue 5, Sept/Oct 2003, p. 626-636.

2. Kaminska, M. E. High-strength concrete and steel interaction in RC members. Cement and Concrete Composites, Vol 24, Issue 2, April 2002, p. 281-295.

3. Lessard, M. and Aitcin, P. C. Testing high performance concrete. In: High performance concrete - from material to structure. Ed by Y. Malier, Van Nostrand Reinhold Inc, New York, 1992.

4. Pendyala, R.; Mendis, P. and Patnaikuni, I. Full-range behaviour of high-strength concrete flexural members: comparison of ductility parameter of high-strength and normal-strength concrete members. ACI Structural Journal, Vol 93, Issue 1, Jan/Febr 1996, p. 30-35.

5. Tomaszewicz, A. Design models in analysis of reinforced and fiber reinforced HPC members. In: Proc of 6th International Symposium on utilization of high-strength/highperformance concrete, 16-20 June, 2002, Leipzig.

6. Yamada, M. and Matsuura H. High-strength concrete for prestressed concrete. In: Proc of International Conference on high-strength concrete, Kona, Hawaii, US. Engineering Foundation Conference, July 13-18, 1997.

7. Yamada, M.; Matsuura, H. and Kumai, H. Hybrid reinforced concrete beams by high-strength and normal concrete. In: Proc of $5^{\text {th }}$ symposium on high performance and high strength concrete, Sundefjord, Norway, June 1999, p. 925-934.

8. Lapko, A.; Sadowska-Buraczewska, B. and Kowalczyk, R. Effects of strengthening of normal concrete beams by high strength concrete layer. In: Proc of National Conference "Structural concrete - 2002", 27-29 Nov 2002, Lisbon, p. 105-112.

9. Lapko, A.; Sadowska-Buraczewska, B. and Nikitin, V. Effectiveness of high-strength concrete application in RC sandwich beams. In: Proc of International Conference „Behaviour of concrete at high temperatures and advanced design of concrete structures“, 3-7 Febr 2003, Minsk, Belarus, p. 190-197.

10. Lapko, A.; Sadowska-Buraczewska, B. and Tomaszewicz, A. Behaviour of reinforced normal and high performance concrete composite members subjected to bending. In: Proc of $8^{\text {th }}$ International Conference ,Modern building materials, structures and techniques", May 19-21, Vilnius, Lithuania. Selected papers. Ed by E. K. Zavadskas, P. Vainiūnas and F. M. Mazzolani. Vilnius: Technika, 2004, p. $547-552$.

11. CEB Bulletins d'information 197. High-strength concrete - Joint FIP/CEB State-of-the-Art Report, 1990. 61 p.

12. PN-B-03264:2002. Polish Standard: Plain, Reinforced and Prestressed Concrete Structures. Analysis and structural design. (Konstrukcje betonowe, żelbetowe i sprężone. Projektowanie i obliczenia statyczne). Polish Committee for Standardization, Warsaw, Poland, 2002 (in Polish).

13. prEN 1992:2003. Eurocode 2. Design of concrete structures - Part 1: general rules and rules for buildings. Dec 2003.

\section{STIPRIOJO LABAI FUNKCIONALAUS BETONO LANKSČIŲ KOMPOZITINIŲ SIJŲ EKSPERIMENTINIS IR TEORINIS TYRIMAS}

\section{A. Lapko, B. Sadowska-Buraczewska, A. Tomaszewicz}

Santrauka

Pateikiami iš normalaus stiprio bei labai funkcionalių betonų pagamintų kompozitinių sijų eksperimentinès bei teorinès analizès rezultatai. Bandymai buvo atlikti su $120 \times 200 \mathrm{~mm}$ skerspjūvio ir $2950 \mathrm{~mm}$ tarpatramio gelžbetoninèmis kompozitinėmis sijomis. Pagrindiniai bandiniai buvo pagaminti iš dviejų sluoksnių: iš labai funkcionalaus betono (viršutinejje skerspjūvio dalyje) bei normalaus stiprio betono. Analizès rezultatai parodè kompozitinių sijų ir sijų, pagamintų vien tik iš normalaus stiprio betono, esminius savybių bei elgsenos skirtumus. Palyginti rezultatai, gauti išbandant sijas, pagamintas vien tik iš labai funkcionalaus betono.

Raktažodžiai: kompozitinė sija, labai funkcionalus betonas, laikomoji galia, deformavimas, natūralaus dydžio sijos bandymai.

Andrzej LAPKO. Prof Dr Habil. Head of Dept of Structural Concrete, Bialystok Technical University, Poland. Professor (1999); Doctor Habil (technological sciences), 1990; Assoc Prof (1993), Doctor (technical sciences), 1978. Research interests: reinforced concrete structures, particulary large capacity silos and tanks, analysis and design of reinforced concrete structures, application of high-strength concrete.

Barbara SADOWSKA-BURACZEWSKA. Dr Techn Sc 2005; Dept of Structural Concrete, Bialystok Technical University, Poland. Research interests: reinforced concrete structures, analysis and design of composite reinforced concrete structures with the use of high strength concrete.

Andrzej J. TOMASZEWICZ. Dr Techn Sc. Researcher involved in more than 20 years in scientific projects at The Foundation for Scientific and Industrial Research at the Norwegian Institute of Technology (SINTEF), also active as a scientific adviser at the Norwegian Society of Professional Engineers. His professional interests are ranging from development of new concepts in structural engineering to implementation in design. A contributor to the Norwegian developments on the use of high-strength concrete in off-shore structures and other applications including composite reinforced concrete structures. 